\title{
The Importance of Choosing One of the Egyptian Ports As A Mega Container Terminal to Compete Globally.
}

\author{
By:
}

\section{Dr.Sherif Maher Heakl '}

\footnotetext{
'Associate professor of Ports \&Shipping Management, Associate Dean of Continuing Education College-Arab Academy for Science and Technology and Maritime

Transport, Alexandria, Egypt.

E-mail: shsm14@hotmail.com
} 


\begin{abstract}
Greater attention has been given to trade costs in both the empirical trade literature and in theoretical models of international trade in recent years, with interest increasingly being directed towards the role of no policy barriers such as transport costs. However, if distance is a proxy for transport and other trade costs, then the true effect of transport costs is impossible to determine. We attempt to remedy this by utilizing the newly compiled project of Suez Canal for Economic Co-operation and Development Maritime Transport Cost as a whole and the most important element of it, which is port efficiency.
\end{abstract}

The dredging projects in the Suez Canal, the intention for the creation of new terminals in Asia and Europe are only some of the actions taken already for the shift to the new era. However, as it is very common in the history of technology and engineering achievements, many suggest that this size of the vessels is going to be the last frontier of their physical expansion, not because of technical restrictions and limits but because of the achieved economies of scale.

Recent literature has emphasized the importance of transport costs and infrastructure in explaining trade, access to markets, and increases in per capita income. For most, transport costs are a greater barrier to markets than import tariffs. Distance, volumes, and product characteristics all matter. In addition, the researcher fined that port efficiency is an important determinant of shipping costs. Improving port efficiency from the 25th to the 75th percentile reduces shipping costs by $12 \%$. Bad ports are equivalent to being $60 \%$ farther away from markets for the average country. Inefficient ports also increase handling costs, which are one of the components of shipping costs. In turn, factors explaining variations in port 
efficiency include excessive regulation, the prevalence of organized crime, and the general condition of the country's infrastructure. Reductions in country inefficiencies, associated to transport costs, from the 25th to 75th percentiles imply an increase in bilateral trade of around $25 \%$. $^{2}$

Therefore, this research will examine most of the factors affecting Egypt's port efficiency to stand as a pivot of trade in the Mediterranean routes, highlighting the strategy that can achieve the future prospect of Egypt's ports or one of them as logistics center. This will turn many benefits to Egypt's Economy and establishing new projects in the region also attract investors to invest in many activities related to that.

\section{Research objective}

To identify the importance of Egypt's port development to play the expected role in the national project of Suez Canal. Illustrating the importance of value added factors, which must associated with port's development to join the global race of new international trade, global logistics and supply chain.

\section{Research question}

What are the best practices to develop Egypt's port management consequently enhance its efficiency to cope with the global logistics and supply chain, and also utilize the presence of Suez Canal international passage in its region and become logistics canter.

\section{Research Methodology}

Stranded in the nature and the purpose of this study, the qualitative method applies to the project work based on the essay format. Hence the study based mainly on desk study.

\footnotetext{
${ }^{2}$ www.BIMCO.org
} 


\section{Research outline:}

The research deals with the following points:

\section{1-Introduction}

1-1 The Shipping Market and Global Economy.

1-2 Shipping Supply.

1-3 Shipping Demand.

\section{2-Cretirea for choosing the Best Mega Container Terminal in} Egypt.

\section{3- Development the Suggested Mega Terminal.}

\section{4- Suez Canal, Mega Container Terminal and Global Competition.}

\section{5- Conclusion.}

\section{1-Introduction:}

The international shipping industry has an undisputed, major contribution to global transportation \& logistics. The shipping industry has historically been highly cyclical, experiencing significant volatility in vessel values, freight rates and shareholder returns. It is highly affected by changes in the international economic and political environment. Increasing regulation, volatility in financial markets, risk of piracy, technological breakthroughs and environmental concerns have added to a very challenging business environment that puts even experienced shipping executives to the test.

Postal operators and large logistics providers play a dominant role as key stakeholders in the transportation and logistics industry. In recent years some former national Posts changed completely to become multinational providers of complex logistics and financial services.

At the same time, former Posts profit from their years of experience in collecting, processing, transporting and delivering national and international mail in order to develop and provide a broader palette of logistics based services. Further, many existing logistics and express companies have expanded 
beyond simple delivery services and are now managing processes along the entire supply chain. These ongoing trends have changed the face of an industry which has become increasingly focused on serving customers in all parts of the world.

\section{1-1 The Shipping Market and Global Economy:}

2014 started with plenty of optimism for a considerably better global economy and an improved shipping market. Things turned out somewhat differently. Adverse weather conditions in the US during winter were the dominant factor, creating a difficult first half of the year for the global economy. The developing and emerging markets continued on a downward trend, while a sunnier outlook from the US and Europe had the effect of moving the already more advanced economies forward.

Growth in emerging markets and developing economies is set for a comeback in 2015, with GDP-growth improving from 4.4\% in 2014 to $5.0 \%$ in 2015 . The advanced economies are likely to stay on the recovery track, and improve their GDP-growth to $2.3 \%$ in 2015 (1.8\% in 2014). The common challenges remain poor inflation expectations, a lack of structural reforms and lack of job creation. There is clearly room for more political initiatives in 2015 to support the global economy.

Growth in GDP, merchandise trade and seaborne shipments are interlinked and continue to move in tandem (figure 1) Trade can generally grow faster or slower than GDP, although since the 1990s it has tended to grow about twice as fast (WTO, 2014a). As merchandise trade expanded at nearly the same rate as GDP the validity of the established historical ratio between GDP and trade is being questioned. 


\section{Figure (1): The OECD Industrial Production Index and indices for the}

world: Gross domestic product, merchandise trade and seaborne shipments, 1975-2013 $(1990=100)$

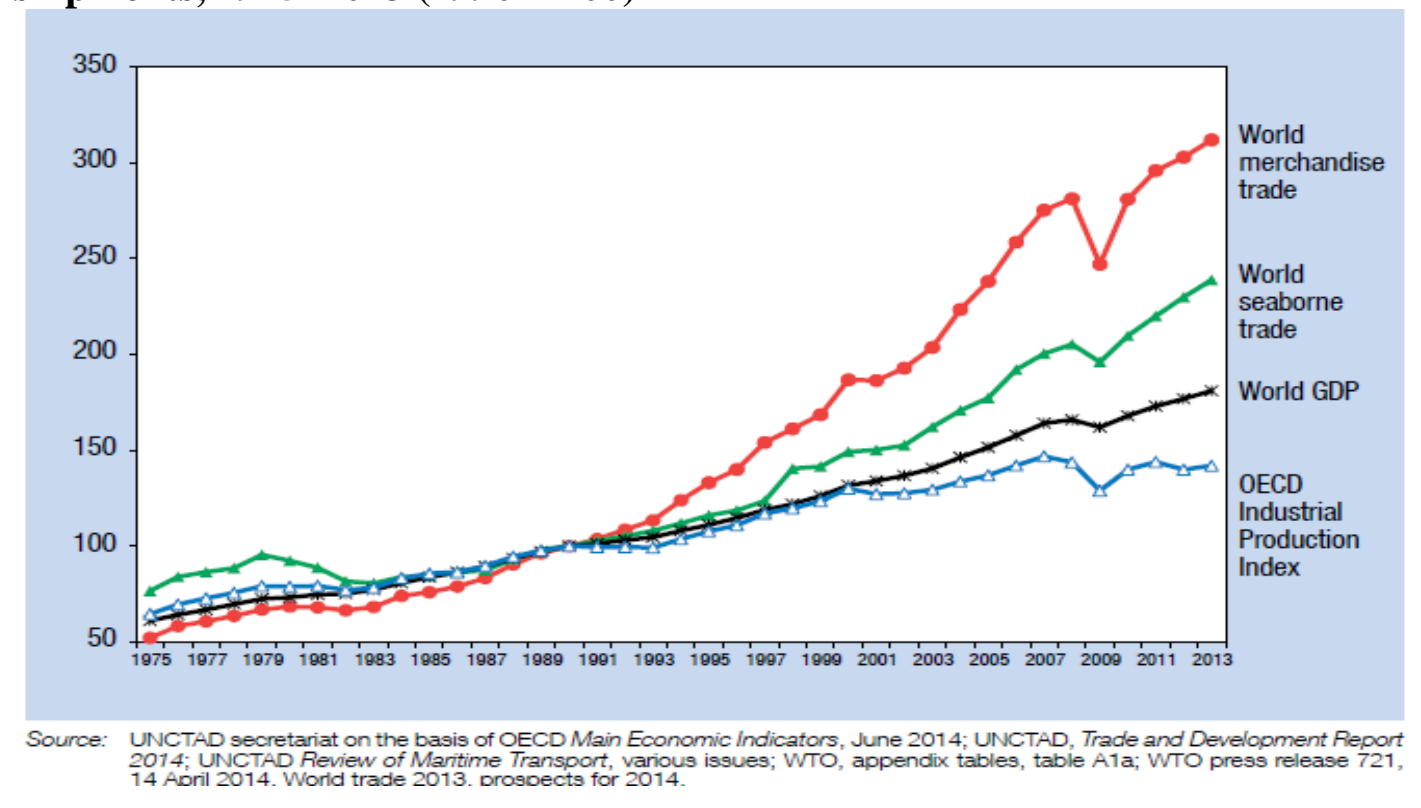

\section{1-2 shipping Supply:}

The total order book remained unchanged during 2014. This signals that the industry is now realizing that more new orders may not be the right thing to do after all.

The fundamental oversupply of capacity in all of the major shipping segments has not changed much over the past year. A higher level of demand has only just matched the net supply of new tonnage coming on stream.

Crude oil tankers are the only exception to the general status quo in the balance of freight markets. A multi-year low inflow of new crude oil tankers has stimulated earnings growth of some 20\% compared to 2013. Meanwhile, the growing supply pressure in product tankers neutralized most of the growing demand side, with earnings coming in just a little shy of 2013. 
Container ships keep getting bigger, breaking previous size records for both individual ships and the average size across the fleet. The CSCL Globe, with a capacity of 19,000 TEU, was launched in November, and the average TEU capacity of a 2014-newbuild increased to 7,400 TEU, up from 6,600 TEU in 2013. Next year the scheduled average is 8,000 TEU. Figure 2 shows World fleet by principal vessel types, 1980-2014 (Beginning-of-year figures percentage share of $d w t)$.

Looking forward to 2015, BIMCO expects the dry bulk fleet to have found a new "normal" level of supply side growth, expanding by 5.1\% (5.5\% in 2014). Regrettably, the level is still too high to reduce the glut of ships in the market. For tankers, BIMCO expects the dirty segment to grow by $1.7 \%(1.3 \%$ in 2014). Three years of low supply growth has led to more positive short-term prospects for crude oil tankers. In the clean segment, the estimated supply growth for 2015 is $4.6 \%$ (4.3\% in 2014). Supply growth in the container ship segment is expected to drop to $5.8 \%$ in 2015 (6.2\% in 2014).

Figure (2): World fleet by principal vessel types, 1980-2014 (Beginning-ofyear figures percentage share of dwt)

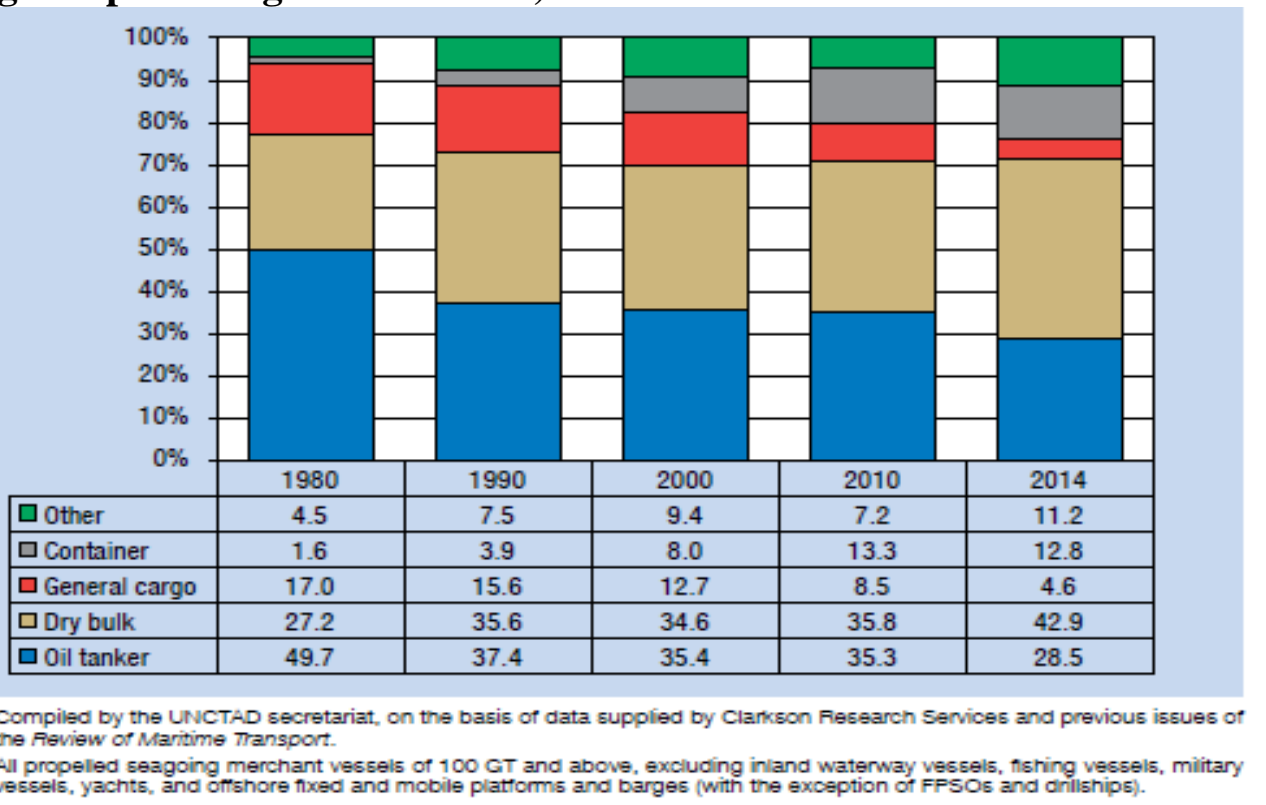




\section{1-3 shipping Demand:}

Strong demand growth on the large-volume trades from Far East to US and Europe has brought lower volatility in freight rates on key trades while reactivating most of the previously idle ships.

However, during peak season, the steep drop in freight rates on the Far East to Europe trade lane made it clear that the utmost care is constantly required for the supply side, while the introduction of ever-larger ships continues.

Improved industry earnings currently rest on one central requirement: slow steaming and defense of individual market share. This highly competitive market only returns a positive margin if the cost base is extremely low.

BIMCO expects containership supply to continue to grow at its "new normal" level of around 6\%, as shown in fig (3), making the demand side a focal point. European demand has been stronger than private consumption figures indicated, and we may well see further improvement for US demand. The US East Coast could build further on a remarkable year as the ports prepare for the imminent arrival of ultra-large container ships. Enlargement projects in the Panama Canal and Suez Canal will further influence the deployment of ships. 
Figure (3): Trends in deliveries of geared container ships, 2005-2013 (New container ships with own container-handling gear, percentage of total container-ship deliveries)

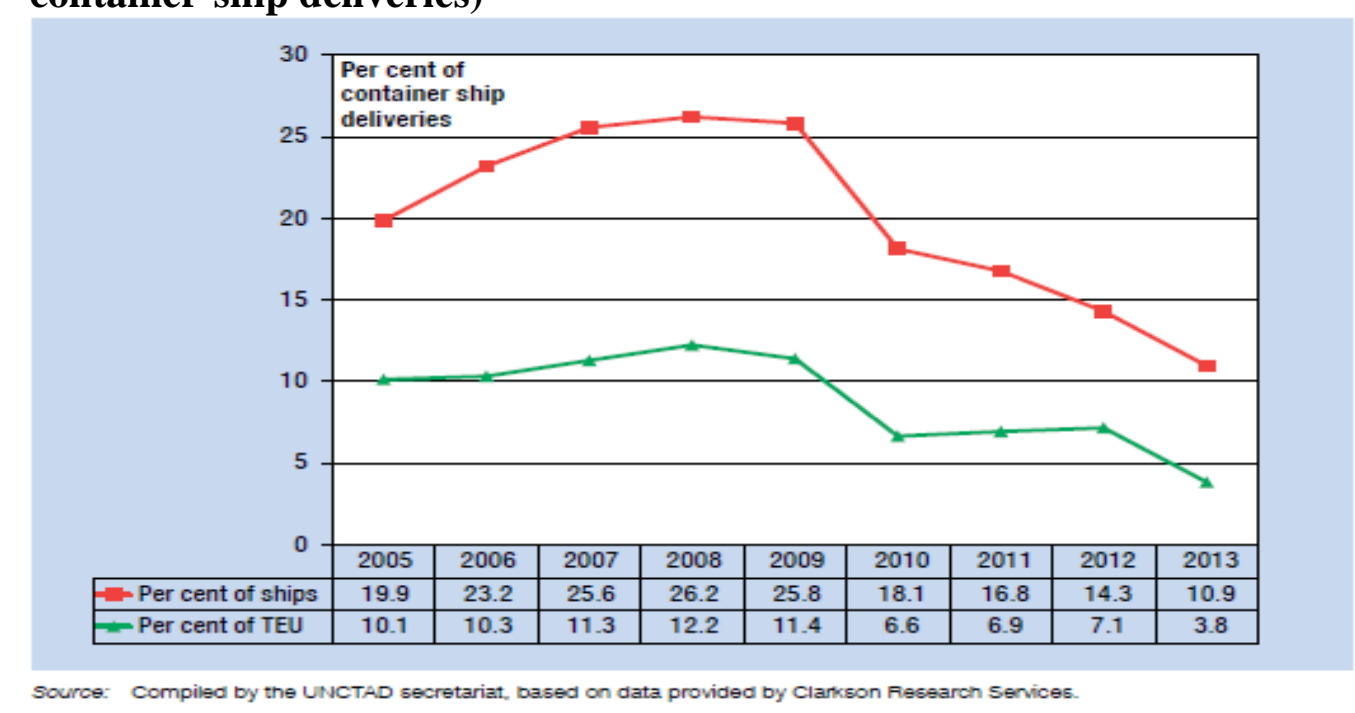

\section{2-Cretirea for choosing the Best Mega Container Terminal in Egypt:}

The transportation sector is the Trojan horse of economic growth in Egypt, as transportation networks are considered the arteries which economic and social activities flow through, where all sectors of the national economy depend on the services and facilities of this sector to link both production and consumption markets together, besides having the access to the needs of raw materials and services and operating.

Egypt's unique geographic location combined with an expanding infrastructure base is enhancing the country's position as a key global logistics hub for companies looking to do business in, or trade between, Europe, Asia and Africa.

The Suez Canal is crucial to both global shipping and to the Egyptian economy, with the waterway representing one of the biggest revenuegenerators in Egyptian trade. It connects the Red Sea to the Mediterranean and 
acts as the country's major source of foreign currency, which is also generated by oil and gas exports, tourism and remittances from Egyptians living abroad.

New rules for the Suez Canal, implemented in February, could save large container vessels on the back voyage to Asia from Europe as much as half a day in sailing time. The vessels will now be able to join the second southbound convoy of the day. This has been made possible by work in the Ballad bypass, which has enabled it to accommodate TEU carriers up to 13,000 capacities...

With $8 \%$ of the world's maritime shipping passing through the Suez Canal each year and an increasing number of international companies from India and China to Turkey and Spain using Egypt as a manufacturing base for exports targeted at the European market, Egypt's logistics and transportation sector is playing an increasingly vital role in international trade. About $90 \%$ of Egypt's foreign trade is shipped through ports, while the country's logistics has to be introduced and implemented with enough capacity to expand hand-in-hand with the volume of trade.

The presence of the Suez Canal in Egyptian territory provides an important source of income in fees and associated businesses to the Egyptian economy; those ports expected to see strongest growth in 2014 are those located near the canal, such as East Port Said, which will also benefit from the improved global macroeconomic picture.

Accounting for $3.1 \%$ of GDP in FY2014/15 (fiscal year running from JulyJune),, Egypt's logistics and transportation sector encompasses more than 108,000 kilometers of paved roads, 9570 kilometers of railways, globally ranked airports in all major urban centers, including an air cargo airport of five terminals in Cairo, six seaports on the Mediterranean and nine on the Red Sea, six dry ports and an extensive network of Nile river transport facilities. ${ }^{3}$

Whereas the slow pace of recovery of the global economy fails to ease the pain in the global shipping industry significantly, the "no increase of Suez Canal tolls" announcement by the Suez Canal Authorities is a welcome easing.

\footnotetext{
${ }^{3}$ Source: Egyptian Maritime data bank
} 
On 4 February 2015 the Suez Canal Authority published its Transit Dues for the year 2015, stating that there will be no increase of tolls for 2015. They shall thus remain unchanged from 2014. Only exception to the overall respite is an increase of $10 \%$ for LNG ships as the standing 35\% reduction in tolls changes from 1 May 2015 to a $25 \%$ reduction.

Chief Shipping Analyst at BIMCO, Peter Sand, says:

"As the global economics to not provide any respite, this announcement is welcome.

"Dry bulk shipping industry is particularly hard hit at the moment, with the BDI hitting a 3-decade low level.

"Any offsetting of the cost escalation of daily operations is useful. Bunker prices are down 60\% from 7 months ago and now unchanged tolls are well received.

"Realizing that now is not the time for price hikes, show that the Authority is aware of the serious condition of global shipping."

There is plenty of room for growth in the sector. Domestic enterprises are shifting their focus to export markets, while increases in per capita income have led to increased demand for imported and locally produced goods. All of this has translated into a strong demand for efficient physical transport infrastructure and logistics services.

Despite the extensive coverage of road and rail networks and significant development of port facilities, investment opportunities in Egypt abound. Some areas, such as Egypt's rail network, are in need of significant infrastructural improvement. Other subsectors, including ports and dry ports, offer investment opportunities in value-added services alongside large development projects. All facets of the sector are approaching maximum capacity, with major capacity shortfalls forecast over the coming five to ten years.

Egypt's Suez Canal registered an $8.5 \%$ year-on-year (y-o-y) rise in revenues to about EGP3bn (USD441.9mn) in March, compared with EGP2.8bn (USD407.4mn) in the same month in 2013. The canal posted nearly EGP2.4bn (USD339.3mn) in revenues in February. The Suez Canal is one of Egypt's 
main sources of foreign currency and is the fastest shipping route between Europe and Asia ${ }^{4}$.

The real consideration of all port authorities in the Mediterranean including Egypt is the hinterland connections. Most of the terminals are poorly connected to the land networks and congestion or other social costs downgrade the image and the efficiency of the industry. Intermodality becomes more than a policy decision and becomes imperative when dealing with the volumes of mega-carriers.

${ }^{4}$ Source: Atlas Marine Services Co. S.A.E. 
The next table Number (1) shows the opportunities of Suez Canal region to developed, and the chances provided to investors utilizing the comparative advantage of this region to international maritime transport and global logistics

Table (1): Suez Canal territory advantages.

\begin{tabular}{|c|c|c|}
\hline Sector Drivers & $\begin{array}{l}\text { Egypt's Value } \\
\text { Proposition }\end{array}$ & Investor Benefits \\
\hline Geographic Location & $\begin{array}{l}\text { Egypt is close to major } \\
\text { markets in Europe, } \\
\text { Africa and the Middle } \\
\text { East. Ships leaving } \\
\text { Egypt take less than one } \\
\text { week to reach major } \\
\text { ports in Europe and the } \\
\text { Arab world. For } \\
\text { container ships leaving } \\
\text { Asia headed for Europe, } \\
\text { Egypt is a logical } \\
\text { transport venue. }\end{array}$ & $\begin{array}{l}\text { Located on key } \\
\text { international logistics } \\
\text { routes with proximity to } \\
\text { strong regional markets } \\
\text { and major export } \\
\text { markets. }\end{array}$ \\
\hline Built-in Markets & $\begin{array}{l}\text { Some } 8 \% \text { of world } \\
\text { maritime trade flows } \\
\text { through the Suez Canal } \\
\text { each year, with ample } \\
\text { opportunities for } \\
\text { ship/container repair and } \\
\text { value added services. In } \\
\text { addition, Egypt's } \\
\text { burgeoning } \\
\text { import/export trade } \\
\text { requires logistics and } \\
\text { transportation solutions. }\end{array}$ & $\begin{array}{l}\text { Built-in markets provide } \\
\text { a broad customer base } \\
\text { and variety of } \\
\text { opportunities for } \\
\text { logistics and } \\
\text { transportation } \\
\text { companies looking to set } \\
\text { up shop in Egypt. }\end{array}$ \\
\hline
\end{tabular}




\begin{tabular}{|c|c|c|}
\hline $\begin{array}{l}\text { Underdeveloped } \\
\text { and Expanding } \\
\text { Sector }\end{array}$ & $\begin{array}{l}\text { Growing demand is } \\
\text { causing capacity shot } \\
\text { falls in the nation's } \\
\text { logistics and } \\
\text { transportation sector, } \\
\text { which is currently } \\
\text { underdeveloped in terms } \\
\text { of both infrastructure } \\
\text { and services. }\end{array}$ & $\begin{array}{l}\text { Major investment } \\
\text { opportunities from } \\
\text { infrastructure projects to } \\
\text { value-added services } \\
\text { and the ability for } \\
\text { investors to attain large } \\
\text { market share. }\end{array}$ \\
\hline Labor Force & $\begin{array}{l}\text { Egypt has a large, } \\
\text { educated, trained and } \\
\text { competitively priced } \\
\text { labor force eager to } \\
\text { work in such sectors as } \\
\text { logistics and } \\
\text { transportation. A } \\
\text { government-run } \\
\text { industrial training } \\
\text { program is providing } \\
\text { hundreds of thousands } \\
\text { of skilled workers for } \\
\text { the industry. }\end{array}$ & $\begin{array}{l}\text { Low labor costs } \\
\text { combined with } \\
\text { educated, skilled labor } \\
\text { improve profitability } \\
\text { year after year. }\end{array}$ \\
\hline $\begin{array}{l}\text { Government } \\
\text { Spuport }\end{array}$ & $\begin{array}{l}\text { The government is } \\
\text { pushing for Egypt to } \\
\text { become a global } \\
\text { logistics hub and is } \\
\text { opening up opportunities } \\
\text { for foreign investment } \\
\text { across the sector. } \\
\text { Industrial free zones are } \\
\text { often located at or very } \\
\text { near major ports. }\end{array}$ & $\begin{array}{l}\text { Improved ease of doing } \\
\text { business and } \\
\text { government facilitated } \\
\text { investment } \\
\text { opportunities. }\end{array}$ \\
\hline
\end{tabular}


Source: Invest in Egypt (2015), brochure publication, Egypt Economic Forum.

Logistics and Port practice has grown in step with the industry, supporting clients through industry restructurings, regulatory transformations, technological advances, changes in financial reporting and new corporate governance requirements. Experience and network of dedicated logistics and port industry practitioners should provide clients with quality audit and business advisory services uniquely tailored to the specific needs of national and multinational post companies and logistics service providers.

\section{3-Development the Suggested Mega Terminal:}

Egypt has numerous maritime facilities on both the Mediterranean and Red Sea coasts.

Egypt has 15 commercial and 51 specialized ports (6 tourism, 15petroleum, 9 mining and 21 fishing and 17 berths); six ports are on the Mediterranean and nine on the Red Sea. The four main ports include the multipurpose Alexandria Port, the largest in Egypt, in 2011, the port dominated the largest share of goods handled in the Egyptian ports recording 35.4\% of the total handled in Egyptian ports compared to $21.2 \%$ for the Damietta Port Authority, and 30.6\% for the Port Said Port Authority and $12.8 \%$ for the Red Sea Ports Authority.

Port Said Port Authority is considered the highest port authority regarding the number of containers handled in Egyptian ports, representing 59.3\% in 2011 of the total containers handled by the Egyptian ports. The Port serves as a regional trans-shipment hub for container traffic, while the Suez Port plays an important role in both cargo handling and Suez Canal transit operations.

Egypt does not only benefit from direct canal revenues, but also from its transshipment ports which take advantage of the trade passing through to capture significant volumes.

Total tonnage throughput at East Port Said is forecast to grow by $3.5 \%$ to $26.51 \mathrm{mn}$ tones in 2014, and to average $5.4 \%$ per annum to 2018 .

East Port Said, the largest container-handling facility in Egypt, is one of the former. Managed by international terminals operator APM Terminals, the container port is forecast to see growth of 3.5\% in its gross tonnage in 2014, The Egyptian government has focused on developing and upgrading ports to accommodate larger ships and to increase capacity and handling for a larger 
volume of trade, also, The Egyptian Ministry of Transportation is set to invest EGP67mn (US\$9.6mn) in the dredging of the Damietta Port in order to house huge ships.

In 2011, the number of containers handled through Egyptian ports reached 6.6 million TEUs (Twenty Foot Equivalents), up from 6.2 million TEUs in 2009... Offering storage, cargo handling, customs clearance and other import/export services, dry ports offer an additional method of bridging the expected gap between port capacity and demand that is likely to arise from a projected $4.8 \%$ increase in import/export volume over the next 20 years.

The six strategically located dry ports in Egypt (all accessible by road and one to be accessible by both road and rail) require enhancements to their service portfolios to become integrated logistics centers with efficient operations at lower costs.

Managing the time factor is an important issue in contemporary liner service design. Increased port congestion and infrastructure constraints are some of the reasons impeding shipping lines from delivering impeccable liner services to their customers. Waiting times and delays put pressure on schedule reliability and might incur logistics costs to the customer. This paper assesses the tradeoffs linked to the time factor in liner service schedules from the perspective of a shipping line. The paper not only assesses causes of schedule unreliability, it also discusses the wide array of measures and planning tools shipping lines deploy to maximise schedule reliability.

Supply chain management has become a key competitive parameter in most industries. The availability of container services from all corners of the globe has resulted in a situation where goods are manufactured in locations which have the optimal mix of cost efficiency and access to relevant labor. Consequently, it is increasingly difficult for businesses to use production costs as a competitive advantage. Instead, we have seen a shift to view supply chain management as a key competitive parameter.

Ocean transportation is a crucial part of the supply chain so container service reliability can be a pivotal element for optimizing supply chains.This, which Egypt's policy has to work for utilizing Suez Canal exisistance and the two ports (Port Said\&Damitta). If ocean services have a low degree of schedule 
reliability, it results in significant added costs, and hence undermines the competitive position of the shipper.

Lack of reliability in ocean transportation will force shippers to include buffer time in the supply chain, resulting in added costs for warehouse storage as well as increased inventory costs. Furthermore, significant costs can be accrued for last-minute land or air transportation in the case of critical delays.

The addition of buffer time extends the end-to-end length of the supply chain hence reducing the shippers' ability to respond to changes in customer preferences, negatively impacting overall sales. Finally, very poor reliability may lead to not only lost sales - but also costs incurred when late deliveries result in cancellations of orders.

To most shippers, reliability on individual trade lanes is more important than a global average. Researchers clearly show that different trade lanes also see different carriers providing above-average performance. Shippers could therefore decide to choose different carriers on different trade lanes, in order to maximize the degree of reliability needed. Therefore the shippers must be convincing with reliability of Suez Canal ports to reach the utmost of their goals.

Egypt's ports needs Core Areas for Investment in Road terminals and transit points, rail line expansion, connections and terminals (road - rail), value-added services around ports and dry ports, airport infrastructure especially two main ports port-said (Mediterranean side) and Damietta (red sea side).In fact the researcher is against to increase the number of ports in Egypt, which leads to high internal competition and ignoring the external one. This happened during the last 25 years in Egypt policy towards to its ports. The result of that a huge decline in shipping industry as a whole, weak performance of ports and no order for ships or investing in it. So to reach to the real strategic goal of Suez Canal widening is determine all the efforts to increase the capability, efficiency and management behavior in Port Said and Damietta ports only. Consequently, Egypt can compete through them on international criteria not on local one.

A World that shrinks with progressive improvements in transportation and communications is a fact of 20 th century life. The shrinking process can 
produce new patterns and perceptions of strategic location. In this paper we are looking specifically at nodes in transportation system. In the light of transportation progress, we re-consider some of the time-worn ideas about centrality, accessibility, gateway locations, junction, transit points, and the like. Do some of these notions become irrelevant in the modern transport age? Is it a questions $\mathrm{f}$ shifting geographical scale? Do we need more sophisticated concepts of strategic location? We suggest the answer 'yes' to all three questions. Our illustrations come from an examination of the world's top-ranked container ports. We give primary emphasis to the external geographical relationships of the ports, which is to situational aspects (not to say, however, that site features are inconsequential). We are interested in the seaports users' -i.e., carriers and shippers-perceptions of strategic location. Readily available container throughput data provide and initial platform for empirical research but also give proof that some commercial interests find these ports strategically important to their system.

Egypt's Ports competitors will be extremely fierce, and the only winner will be the carrier, under the assumption that mega-ships will end up profitable and viable. It is considered as very a possible scenario the set-up of new terminals. As Gaia Taurus appeared in the map several years ago, there are similar plans for highly sophisticated terminals on Crete and other locations. While it is not really clear the rational and the targeted outcome, a new competitor, operated by carriers may directly hit the Maltese clientele and shift the center of the Mediterranean trade eastwards. In case that piece and economic development replaces war and conflicts in the Middle East, this part of the Mediterranean will attract most of the attention. However, there are always the options of Cypriot and Egyptian ports as it will lead if utilize well the new Suez Canal passage.

For the other ports of the Mediterranean, those willing to avoid the battle of the mega-carriers, the future will be considerably better and less risky, if only they follow the trends of modern logistics. The key for their survival and financial viability will be the active role in the creation of logistics chains and networking. The formation of groups of ports shall be expected. The strategy followed by most ports used to be cost leadership. The total prices of the port services should have been more competitive than those of the rival competitor. As prices are low enough and the operating margins are extremely low to attract financial interests, cost reduction cannot satisfy the port 
management. In contrary there is enough space for the creation of new services, which other ports cannot offer currently and this is the chance of Egypt's ports. Advanced and compatible IT systems along with other advanced logistics services, such as reverse logistics considerations, can create needs and make the user willing to pay.

Egypt's ports have a Unique Geographic Position as they are Located at the crossroads of international trade between Europe, the Middle East, Africa and Asia, Egypt is trying to positioning itself to become a major global logistics hub. Businesses are increasingly seeking to base themselves in Egypt as a springboard to Europe and booming regional markets.

In addition Egypt's ports have Rising Domestic Demand. A growing domestic demand for imports and a rapid rise in export-oriented businesses are creating strong demand for logistics and transportation services in a market that is far from saturated.

Also, Ports of Egypt have Greenfield opportunities exist in subsectors such as the road network, which is the most used means of transporting freight but currently has no logistics provider with a consistent distribution infrastructure. Almost all areas have reached capacity ceilings, providing rich opportunities for investment from infrastructure to specialized value-added services.

\section{4- Suez Canal, Mega Container Terminal and Global Competition:}

The position of Egypt within the global liner shipping network depends largely on four factors: its geographical position, its captive cargo base, its port characteristics and the regulatory framework for the liner shipping market. These four determinants will be briefly discussed in this section. ${ }^{5}$

\section{Geographical position}

\footnotetext{
${ }^{5}$ UNCTAD organized an ad hoc expert meeting held in Geneva on 11 July 2014, timed in the lead up to the 2014 Third International Conference on Small Island Developing States (Samoa Conference).
} 
Lying close to the main shipping routes (Suez Canal) or next to a large trading nation makes it easier for a port to attract liner companies and become a port of call.

\section{Port characteristics}

Shipping lines will be more inclined to connect a country's ports to their global liner network if they can rely on modern infrastructure and efficient operations. This issue is also closely linked to the determinants of transport cost. If the port is considered to be costly from the carrier's perspective, the carrier will also skip it and not call, or increase its freight charges to the shipper.

\section{Shipping markets}

Especially for Egypt with several ports, or neighboring where different regions may be close to seaports in a neighbor's territory, it may be convenient to allow foreign countries to connect these ports and not be limited by any market restrictions. An example that proved to be successful

In improving the country's global connectivity and reduce its maritime freight costs is New Zealand. By liberalizing the cabotage between the northern and the southern ports, international shipping lines were

Able to combine international services with cabotage

Services. This has made it attractive to deploy more ships on more frequent services than before, when the inter-port trade was reserved for national-flagged companies.

The present paper indicates the importance of ports management especially in Egypt, and its reflection to port's efficiency needed nowadays. The differences in port terminal management systems are regionally based in Egypt. Not likewise the other countries on macro level. In USA and Europe exhibit different models of port terminal management, despite strong centralizing forces as a result of globalization. At the same time, differences persist between France and the rest of the European Union. The present study has demonstrated that concentrating on one or two ports only in Egypt is important to compete internationally, but still another side for this strategy, which is the uniqueness of port management in all Egypt's ports, which is crucial issue. For example France adapts the uniqueness in its ports, which has significant consequences for the performance levels and competitiveness of its ports. This suggests that while there are significant economic and operational consequences for one mode of global management system over another.

At the same time, an important question about whether these 
Distinctions in Egypt's ports are temporary needs to be addressed. Will globalization impose standardization on the industry in the long run?

One of the major concerns arising out of the developments in terminal

Management in Egypt is the growing concentration of ownership in the terminal management sector to join the global race, especially with new Suez Canal project. In many European ports, the leading terminal company Accounts for between 50 and $100 \%$ of the total traffic (Notteboom, 2002) ${ }^{6}$. In Europe, the three leading TTOs, HPH, PSA and Euro gate, control $72 \%$ of the total market. This concentration is taking place in parallel with the growing concentration of ownership in the world's container shipping industry. The market share of the top 20 carriers has almost reached $80 \%$ (see figure number 4).

Figure (4): Top 20 ship owning nations, beneficial ownership, 1 January 2014 (1,000 dwt, by country/economy of ownership)

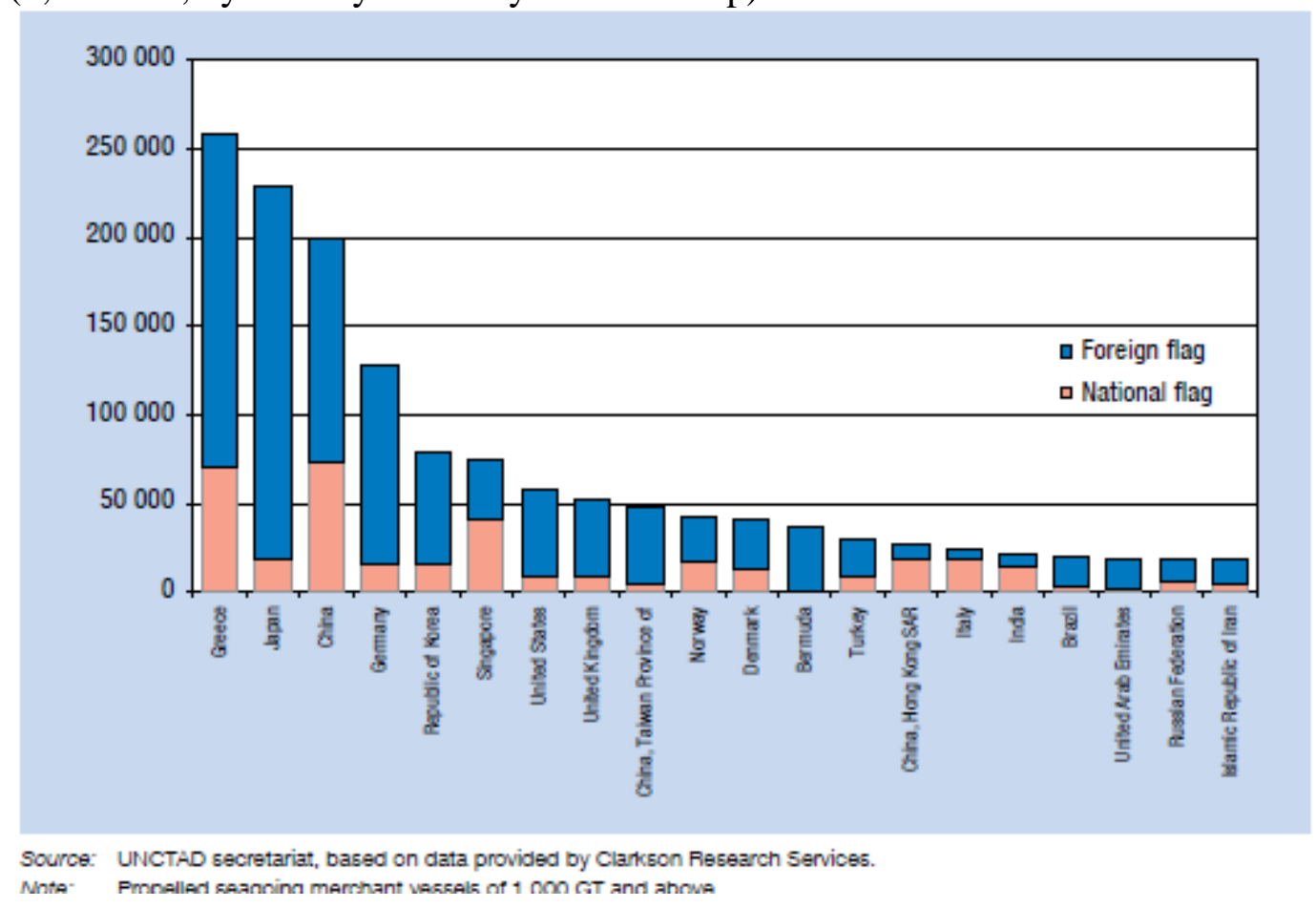

6 Notteboom, T. (2002) Consolidation and contestability in the European container handling industry, Maritime Policy and Management, 29(3), pp. 257-269. 
This is giving rise to concerns about ports becoming private monopolies. Liberalization may have released many ports from national monopoly control, but in its place have emerged private oligopolies (Notteboom, 2002) ${ }^{7}$.

The issue of monopoly concentration is of particular significance in the context of Egypt's ports management development, where the government has to integrate ports into the Trans Networks. Internal port competition appears to be at odds with the actual power of Egypt's ports Competition within and between ports appears to be marked increasingly by competition between the different terminal networks in the world especially those ports in the different ends of Suez Canal.

In seeking to promote port efficiency, are Egyptian policy-makers indirectly favoring monopolies that will limit the abilities of local public interests to intervene in planning Egypt's transport networks?

The two major types of port terminal operations, the multi-user terminal

Management Company and the dedicated berth managed by a shipping line, represent outcomes of different economic processes.

The shipping lines' interest in berth management is a manifestation of vertical integration. The contemporary growth of both models appears set to place them on a trajectory that may lead to future conflicts. With

Increasingly more major ports ceding operations by government, the lines are likely to extract dedicated terminal space from the Egypt's port authorities, something they have largely resisted so far. Which model will prevail? Financially, the terminal industry appears to be in much better shape than the shipping industry, but the shipping lines are generally much larger companies, with greater capitalization. The lines are customers of the port and have the ability to shift from one to the other, and so may have advantages in future competition after the new Suez Canal. On the other hand, it may be that in future the two ports (port said and Damietta) will find it better to cooperate, either in loose strategic alliances or in formal mergers under one management control, which preferably to be private sector.

The 'hybrids' may be the direction in which the industry is heading in Egypt. As companies that manage terminals, they are affiliated with shipping line groups and have grown in part by taking over former terminal operators.

\footnotetext{
${ }^{7}$ Previous reference
} 
The economic efficiency of dedicated terminals (Port Said and Damietta) versus common user facilities is a basic research question. The evidence is unclear. Some research suggests that multi-user facilities achieve higher levels of performance $(\text { Turner, 2000) })^{8}$, while Transformation of Port Terminal Operations other studies claim higher throughputs for dedicated facilities (Carriou, 2003) ${ }^{9}$.

Research in this area is necessary to determine which model is best suited to what particular type of port. However, the present study suggests that cost differentials are not the only determinant, and that governance, institutional relationships and spatial competition, factors that are regionally differentiated, are additional considerations. An important question, therefore, is whether or not these forces of regional differentiation diminish or grow. Finally, the question is raised of whether public authorities may be forced to act to curb growing threats of monopoly power in ports, but with the continued expansion of both public authority and shipping lines in terminal operations in many regions, the ability to exert power over local

And regional supply chains is enhanced, and the interests of local port Communities are diminished. These are important questions, the answers to which will help in the understanding of the nature of globalization and maritime transport, which will focus on government (public port authority) role, is to supervise only without any interference in terminal management and operation.

IN the context of concentration on port said and Damietta, the researcher suggest that two ports specialized to handle only container and become like mega container terminal only and other ports specialized in its main cargo traffic .

Such large infrastructure projects and superstructure needs demand capitals and time, not only for the construction or the supply, but also for the maturity of the

\footnotetext{
${ }^{8}$ Turner, H. S. (2000) Evaluating seaport policy alternatives: a simulation study of terminal leasing

policy and system performance, Maritime Policy and Management, 27(3), pp. 283-301

${ }^{9}$ Carriou, P. (2003) Dedicated terminals in container ports: a cost-benefit analysis. Paper presented at

the International Seminar: Maritime Transport, Globalization and Regional Integration, Le Havre,

June.
} 
technology. In other terms the first ports to become mega-hubs undertake high risks, while the competitors may learn from their mistakes and the maturity of the technology. Time is also pressing as the mega carriers are currently being built and ports have to react to the challenge.

The capital needs are also very high, and only State owned or controlled ports can invest free from investors' interventions and worries. As the ports become more and more important for the economic feasibility of a logistics link, carriers and shipping lines are entering the port business. These

Schemes can also invest in the necessary infrastructure and undertake the risks. The rest of the ports can specialize on specific commodities and market niches. So the mega container terminal become sharing in the adventure between public sector, which will finance the infrastructure, and let the superstructure to private sector.

\section{5- Conclusion:}

Whatever its future, it is evident that Egypt's port terminal management has undergone a major changes very recently because of Suez Canal project. The changes have important theoretical and practical implications. At the heart of the developments is the fundamental contrast between the port authorities, which operate terminals for multiple clients, and the dedicated terminals controlled by one shipping line.

Thus, it is observed that while local control in terminal handling can be ceded to international actors, the scope and form of operations may be shaped by locally determined governance issues. the matter, which is not suitable for Egypt economy in the future, while it looking forward for its economic recitation and catch the global race, global logistics and supply chain.

The public agencies in charge of administering and running public-sector ports do not have a profit motive, and as they cannot go bankrupt they carry out their tasks with their eye on budgetary allocations. State-run ports can be justified if the managers of public-sector ports are relieved of sociopolitical obligations and if the market system of penalties and rewards is applied throughout the port sector. 
Efforts by public port administrators to control costs are usually ineffective because they cannot demand commercial standards of behavior from

Pressure groups such as unions, for Governments ignore competition.

Competition alters this situation, enabling costs to be reduced and the Quality of goods and services improved, by compelling firms to face commercial risks, the possibility of financial loss and the threat of bankruptcy.

Egypt's Government should eliminate bureaucratic obstacles that hinder competition throughout the port community and make sure antimonopoly regimes are applicable to cargo owners, port investors and dock workers alike. Successful port modernization requires one thing: private participation. When Government authorities in developing countries like Egypt became aware of the serious deficiencies in their ports (scant competitiveness, high costs and an overstaffed workforce), they saw private-sector involvement as fundamental for putting the ports in order.

Consequently, Egypt's government has to design frameworks for

Facilitating private-sector participation in the ports, generating benefits for Producers, consumers, workers and carriers alike. Private-sector participation in public-sector ports aims to respond to competition.

In essence, Egypt's port policy has to take in its consideration the following recommendations:

1- Concentrate on external competition through Port Said port and Damietta port. It is favorable of letting these ports especially only for containers. In other words making them as a huge container terminal (Mega Container terminal) with many berths can be run by private sector.

2- Giving a fully management autonomy to private sector, without intervene from the government.

3- Determine the most crucial specialization of other Egypt's ports and the government assists in enhancing this specialization with the participation of private sector, e.g. Alexandria port in ferries, Suez port in bulk and oil ...etc.IN other words they become specialized ports rather than general ports, each according the type of its cargo traffic. Also some of these ports devoted to the national shipping companies carrying Egypt's trade. This will encourage many investors to register their ships in Egypt. 


\section{$\underline{\text { References }}$}

\section{$\underline{\text { Books }}$}

1- Arvis, J.-F. Raballand, G. and Marteau, J.-F. (2010), The Cost of Being Landlocked: Logistics, Costs, and Supply Chain Reliability, World Bank, Washington D.C.

2- Carriou, P. (2003) Dedicated terminals in container ports: a cost-benefit analysis. Paper presented at the International Seminar: Maritime Transport, Globalization and Regional Integration, Le Havre, June.

3- Ferrari, C., Percoco, M. and Tedeschi, A. (2010), Ports and Local Development: Evidence from Italy, International Journal of Transport Economics, 37(1), 9-30.

4- Musso E. (2009), Future Developments in Ports. In Meersman H., Van De Voorde E., and Vanelslander T. (eds.), Future Challenges for the Port and Shipping Sector, Informa: London.

5- Notteboom, T. (2002) Consolidation and contestability in the European container handling industry, Maritime Policy and Management, 29(3), pp. 257-269.

6- Parola, F., Satta, G., Persico, L. and Di Bella, E., (2013), Entry Mode Choices in International Markets: Examining the Antecedents of Service Firms' Strategies', International Journal of Globalization and Small Business, 5(1-2), 34-57.

7- Song, D.-W. and Panayides, P. (2012a), Maritime Logistics: Contemporary Issues, Emerald Group Publication: London.

8- Song, D.-W. and Panayides, P. (2012b), Maritime Logistics: A Complete Guide to Effective Shipping and Port Management, Kogan Page: London.

9- Tongzon, J., Chang, Y.-T., and Lee, S.-Y. (2009), How Supply Chain Oriented is the Port Sector?', International Journal of Production Economics, 122(1), 21-34.

10- Turner, H. S. (2000) Evaluating seaport policy alternatives: a simulation study of terminal leasing policy and system performance, Maritime Policy and Management, 27(3), pp. 283-301.

11- Van Den Bosch, F., Hollen, R., Volberda, H., and Baaij, M. (2011), The Strategic Value of the Port of Rotterdam for the International Competitiveness of the Netherlands:

12- Verhoeven, P. (2010), A Review of Port Authority Functions: towards a Renaissance?'. Maritime Policy and Management, 37, 247-270. 


\section{Web sites:}

1- Atlas Marine Services Co. S.A.E.

2- Source: Egyptian Maritime data bank

3- www.BIMCO.org

\section{Conferences:}

1- Invest in Egypt (2015), brochure publication, Egypt Economic Forum.

2- UNCTAD organized an ad hoc expert meeting held in Geneva on 11 July 2014, timed in the lead up to the 2014 Third International Conference on Small Island Developing States (Samoa Conference). 